\section{Evaluation of Alpha One Anti-Trypsin and Haptoglobin in Hypertensive Patients in Elele}

\section{Abstract}

Inflammation is associated with different cardiovascular diseases like in hypertension. This study to evaluate the level of alpha one anti-trypsin (AAT) and haptoglobin in hypertension was carried out on patients attending Madonna University Hospital (MUTH), Elele, Rivers State, Nigeria. The research was done on a total of one hundred (100) subjects. Fifty (50) of this population were hypertensive patients (Test) while fifty (50) were the control. Their age ranged from 45-65 years. Alpha one anti-trypsin and haptoglobin were measured by Mispa Auto-analyzer Nephelometric immunoassay method. The results were analyzed using statistical package for social science (SPSS) version 20 . The results showed a significant increase $(P<0.05)$ in haptoglobin in hypertensive subjects $(120.9 \pm 54.90 \mathrm{mg} / \mathrm{dl})$ when compared with the control $(47.7 \pm 32.61 \mathrm{mg} / \mathrm{dl})$. Haptoglobin was elevated in hypertension. Hence, level of haptoglobin could be used to predict cardiovascular risk in patients with certain disease conditions. The results also showed significant increase $(P<0.05)$ in the AAT level of hypertensive subjects $(293.7 \pm 59.86 \mathrm{mg} / \mathrm{dl})$ compared to the control $(158.8 \pm 52.14 \mathrm{mg} / \mathrm{dl})$ respectively. Alpha one anti-trypsin plays a role as a biomarker in hypertension.

Keywords: Alpha one anti-trypsin; Haptoglobin; Hypertensive patients

\section{Nnatuanya IN ${ }^{1}$, Obeagu El ${ }^{2 *}$, Nnatuanya $\mathrm{CIC}^{1}$, Ogar OA', Stephen $E^{3}$ and Onah $A^{1}$}

1 Deparment of Medical Laboratory Science, Madonna University, Elele, Rivers State, Nigeria

2 Department of University Health Services, Diagnostic Laboratory Unit, Michael Okpara University of Agriculture, Umudike, Abia State, Nigeria

3 Department of Medical Laboratory Science, Nnamdi Azikiwe University Teaching Hospital, Nnewi, Anambra State, Nigeria

\section{*Corresponding author: Obeagu EI \\ झ emmanuelobeagu@yahoo.com}

Department of University Health Services, Diagnostic Laboratory Unit, Michael Okpara University of Agriculture, Umudike, Abia State, Nigeria.

Tel: +2348037369912

Citation: Nnatuanya IN, Obeagu El, Nnatuanya CIC, Ogar OA, Stephen EC, et al. (2017) Evaluation of Alpha One Anti-Trypsin and Haptoglobin in Hypertensive Patients in Elele. Transl Biomed. Vol.8 No.4:131

complex. As it functions to bind free hemoglobin, it allows degradative enzymes to gain access to the hemoglobin while at the same time preventing loss of iron through the kidneys and protecting the kidney from damage by hemoglobin. Hypertension is a major public health threat worldwide. It is important to determine the level of hemoglobin in hypertensive patients in Elele.

\section{Materials and Methods}

\section{Study area}

The study was done in Madonna University Teaching Hospital, Elele, Rivers State, Nigeria.

Subjects: A total of one hundred (100) subjects were recruited
Haptoglobin $(\mathrm{Hp})$ is a plasma $\alpha_{2}$ glycoprotein which binds free hemoglobin, thus, preventing oxidative damage. Reticuloendothelial system removes Haptoglobin-hemoglobin 
for the study. Fifty (50) subjects were hypertensive subjects and 50 were the control. The age of the subjects ranged from 45-65 years.

Ethical consideration: Informed consents were obtained from the subjects.

Sample collection: A $2 \mathrm{ml}$ venous blood sample was collected from the mid cubital vein following aseptic technique and transferred to plain tubes and allowed to clot and retract and the serum collected for the AAT assay.

\section{Determination of alpha one anti-trypsin using Mispa autoanalyser nephelometric immunoassay method}

Procedure: The card was inserted to the card reader slot and R1 added. A $120 \mu$ l of the sample was dispensed to the cuvette, inserted into cuvette holder and was incubated. Then $120 \mu \mathrm{l}$ of $\mathrm{R} 2$ was added and result displayed.

\section{Determination of haptoglobin using nephelometric immunoassay method}

Procedure: The smart card was inserted into the card reader slot and display prompted the addition of R1 and sample. From the R1, $100 \mu$ l was added and also $5 \mu$ of the sample was added into the cuvette and the cuvette placed into the holder, mixed with the machine and after 10 seconds the sample was incubated for 3 seconds. From R2, $100 \mu$ l was dispensed into the cuvette, mixed and the result read.

Statistical analysis: Data obtained from this study were analyzed using the statistical package of social science (SPSS) version 20.

\section{Results}

The results were expressed as mean \pm standard deviation (SD). Independent sample t-test was used to compare means and values considered significance at $\mathrm{P}<0.05$ (Tables 1-4).

Table 1 Showing comparison of alpha one anti-trypsin among the hypertensive and control subjects.

\begin{tabular}{|c|cc|c|}
\hline Parameter & Control & Test & Level of significance \\
\hline AAT $(\mathrm{mg} / \mathrm{dl})$ & $158.8 \pm 52.14$ & $293.7 \pm 59.86$ & $\mathrm{P}<0.05$ \\
\hline AAT: Alpha One Anti-Trypsin & & \\
\hline
\end{tabular}

Table 2 Showing comparison of alpha one anti-trypsin among the subjects based on different age groups with the control.

\begin{tabular}{|c|c|c|c|}
\hline Groups (years) & $\begin{array}{c}\text { Control AAT } \\
(\mathbf{m g} / \mathbf{d l})\end{array}$ & $\begin{array}{c}\text { Test AAT }(\mathrm{mg} / \\
\text { dl) }\end{array}$ & $\begin{array}{c}\text { Level of } \\
\text { significance }\end{array}$ \\
\hline $45-50$ & $182.4 \pm 75.78$ & $277.4 \pm 70.31$ & $\mathrm{P}<0.05$ \\
\hline $51-55$ & $160.1 \pm 41.82$ & $286.4 \pm 69.47$ & $\mathrm{P}<0.05$ \\
\hline $56-60$ & $143.5 \pm 40.52$ & $301.4 \pm 50.75$ & $\mathrm{P}<0.05$ \\
\hline $61-65$ & $155.1 \pm 46.47$ & $306.2 \pm 52.81$ & $\mathrm{P}<0.05$ \\
\hline
\end{tabular}

Table 3 Shows compares between haptoglobin among Hypertensive and control subjects.

\begin{tabular}{|c|c|c|c|}
\hline Parameter & Control & Test & $\begin{array}{c}\text { Level of } \\
\text { significance }\end{array}$ \\
\hline $\begin{array}{c}\text { Haptoglobin } \\
\text { (mg/dl) }\end{array}$ & $47.7 \pm 32.61$ & $120.9 \pm 54.90$ & $P<0.05$ \\
\hline
\end{tabular}

Table 4 Shows the comparison of haptoglobin among hypertensive and control subjects based on different age groups.

\begin{tabular}{|c|c|c|c|}
\hline Groups (years) & Control & Test & $\begin{array}{c}\text { Level of } \\
\text { significance }\end{array}$ \\
\hline $45-50$ & $55.3 \pm 42.79$ & $133.9 \pm 63.09$ & $\mathrm{P}<0.05$ \\
\hline $51-55$ & $50.3 \pm 23.75$ & $134.6 \pm 56.60$ & $\mathrm{P}<0.05$ \\
\hline $56-60$ & $39.1 \pm 30.93$ & $109.4 \pm 54.04$ & $\mathrm{P}<0.05$ \\
\hline $61-65$ & $47.9 \pm 33.04$ & $108.2 \pm 45.67$ & $\mathrm{P}<0.05$ \\
\hline
\end{tabular}

\section{Discussion}

In an attempt to discover the effect of hypertension on the level of alpha one anti-trypsin (AAT) in the body of patients diagnosed with hypertension, it was done to determine the level of AAT in the patients. Alpha one anti-trypsin is secreted into the circulation and increased level can occur as a result of production of tumour, leakage from disease patients, reaction against tissue damage and impaired renal function.

The results showed significant increase $(P<0.05)$ in AAT of hypertensive subjects $(293.7 \pm 59.86 \mathrm{mg} / \mathrm{dl})$ compared to the control $(158.8 \pm 52.14 \mathrm{mg} / \mathrm{dl})$ respectively. This could be attributable to reaction against tissue damage and impaired renal function. Renal diseases have been implicated in the pathogenesis of secondary hypertension and the epithelial cells of the kidney contributes to the remaining $20 \%$ of AAT among other sources.

The results showed that the level of haptoglobin was increased significantly $(P<0.05)$ in hypertensive subjects compared to the control. The increase in haptoglobin level among the hypertensive subjects could be suggesting the possibility for intravascular haemolysis due to vascular damage leading to further complications. Study by Levy revealed an increased level of plasma haptoglobin in patients with hypertension crisis. These results confirmed that during inflammatory process, some acute proteins are raised.

\section{Conclusion}

Alpha one anti-trypsin (AAT) level is significantly elevated in hypertensive subjects and could be concluded that alpha one antitrypsin plays a role as a biomarker in hypertension. The results of this study showed that haptoglobin is significantly increased among hypertensive patients. Hence, level of haptoglobin could be used to predict cardiovascular risk in patients with certain disease conditions. 


\section{References}

1 Zhao P, Alsop D (2010) Hypertension and cerebral vasoreactivity a continuous arterial spin labeling magnetic resonance imaging study. Hypertension 5: 859-864.

2 Devin K, Binder (2004) Idiopathic intracranial hypertension. Neurosurgery 54: 538-552.

3 Amira P (2005) Severe renovascular hypertension in an infant with congenital solitary pelvic kidney. Pediatrics Nephrol 21: 437-440.
4 Martin T (2007) Hypertension clinical features and investigation. Hospital Pharmacist 14: 111-116.

5 Ambiru S (2000) Effects of perioperative protease inhibitor on inflammatory cytokines and acute phase proteins in patients with hepatic resection. Digestive Surg 17: 337-343.

6 Ping-I H (2010) Diagnosis of gastric malignancy using gastric juice 1 1antitrypsin. Can Epidemiol Biomark Preval 19: 405-411. 